\title{
Chronic progressive HIV-1 infection is associated with elevated levels of myeloid-derived suppressor cells
}

\author{
T Vollbrecht ${ }^{1}$, J Roider ${ }^{1}$, R Stirner ${ }^{1}$, A Tufman ${ }^{1}$, RM Huber ${ }^{1}$, JR Bogner ${ }^{1}$, A Lechner $^{1}$, C Bourquin² ${ }^{2}$ R Draenert ${ }^{\text {* }}$ \\ From AIDS Vaccine 2012 \\ Boston, MA, USA. 9-12 September 2012
}

\section{Background}

Myeloid-derived suppressor cells (MDSC) have been described as suppressors of $\mathrm{T}$ cell functions in many tumor models. However MDSC in HIV-1 infection have not been studied to date. As impaired $\mathrm{T}$ cell function is a hallmark of chronic progressive HIV-1 infection, we hypothesized that MDSC also play a role here.

\section{Methods}

Surface staining and FACS analysis were performed on freshly isolated PBMC of HIV-infected individuals and compared to healthy controls and individuals with lung carcinoma. MDSC of late-stage HIV-infected subjects were isolated using magnetic beads and co-cultured with the respective CD8 T cells for evaluation of proliferative capacity.

\section{Results}

We found that chronically HIV-infected HAART-naïve individuals had significantly higher $\mathrm{CD} 11 \mathrm{~b}+\mathrm{CD} 14-\mathrm{CD} 33$ $+\mathrm{CD} 15+$ MDSC levels than healthy controls $(\mathrm{p}=0.01)$. MDSC frequencies showed a positive correlation with viral load $(\mathrm{r} 2=0.24, \mathrm{p}=0.0002)$ and a negative correlation with CD4 count $(\mathrm{r} 2=0.29, \mathrm{p}<0.0001)$. Initiation of HAART led to a rapid drop in MDSC levels. MDSC from HIV-infected progressors restricted the proliferative capacity of CD8 T cells from healthy donors and of Gag/Nef-specific CD8 T cells from HIV-controllers in vitro. Furthermore CD11b+CD14-CD33+CD15+ MDSC induced the expansion of CD4+CD25+FoxP3+ regulatory $\mathrm{T}$ cells when co-incubated with PBMC from controllers in vitro.

'Ludwig-Maximilians-University, Munich, Germany

Full list of author information is available at the end of the article

\section{Conclusion}

We conclude that chronic uncontrolled HIV-infection is associated with elevated levels of MDSC which potentially contribute to the impaired $\mathrm{T}$ cell responses characteristic for the progressive disease stage.

\section{Author details \\ 'Ludwig-Maximilians-University, Munich, Germany. ${ }^{2}$ University of Fribourg, Fribourg, Switzerland.}

Published: 13 September 2012

doi:10.1186/1742-4690-9-S2-P283

Cite this article as: Vollbrecht et al:: Chronic progressive HIV-1 infection is associated with elevated levels of myeloid-derived suppressor cells. Retrovirology 2012 9(Suppl 2):P283.
Submit your next manuscript to BioMed Central and take full advantage of:

- Convenient online submission

- Thorough peer review

- No space constraints or color figure charges

- Immediate publication on acceptance

- Inclusion in PubMed, CAS, Scopus and Google Scholar

- Research which is freely available for redistribution

Submit your manuscript at www.biomedcentral.com/submit 